information may be obtained from the Scientific Film Association, 164 Shaftesbury Avenue, London, W.C.2.

\section{Guide to H.M. Stationery Office Publications}

UNDER the title "The State as Publisher", S. Horrocks, reference librarian of the Manchester Public Libraries, has prepared a useful librarian's guide to the publications of H.M. Stationery Office. This has been issued as Library Association Pamphlet No. 10 and includes a foreword by H. C. C. Welch, controller of the Stationery Office (pp. $32 ; 1952.5 s$.; to members of the Library Association, $3 s .6 d$.$) . Mr.$ Horrocks gives an analytical survey of Stationery Office publications, including parliamentary and sessional papers, parliamentary debates and nonparliamentary publications; and his pamphlet should both assist in the location and acquisition of such publications and also in their handling, for he includes sections on Stationery Office lists and indexes and on the cataloguing of government publications, with details of an interim code for cataloguing, as well as on the arrangement and preservation of such publications. The practical problems which arise are indicated and some suggestions are made for their solution.

\section{Ciba Foundation: Report for 1951}

THE second report from the Ciba Foundation for the Promotion of International Co-operation in the Field of Medical and Chemical Research covers the year ended December 31, 1951 (pp. 32; from the Ciba Foundation, 41 Portland Place, London, W.1; 1952). During the year the Foundation arranged three further colloquia on endocrinology (hormonal influences on water metabolism; hormones, psychology and behaviour; and the control of anterior pituitary secretions) and two general symposia-one on isotopes in biochemistry, and one on visceral circulation. The report includes brief accounts of these colloquia, with lists of participants, and particulars of the eight volumes containing the proceedings of the twelve conferences arranged by the Foundation which are being published by Messrs. J. and A. Churchill. The third Ciba Foundation lecture, delivered by Prof. B. A. Houssay on July 3, 1951, dealt with "Sex Hormones in Experimental Diabetes". Appendixes list the books and periodicals available in the library at the end of 1951 , and a note on the trust deed setting forth the purpose of the Foundation is included.

\section{Mineral Dressing: Symposium in London}

THE Institution of Mining and Metallurgy is arranging a symposium on "Mineral Dressing", to be held at the Imperial College of Science and Technology (Royal School of Mines), Prince Consort Road, South Kensington, London, S.W.7, during September 23-25. The purpose of the symposium is to discuss recent advances in the subject, and more than thirty papers are being prepared to form the basis for the discussion, these being grouped under three headings as follows: fundamental concepts and experimental methods; advances in practice at selected plants; and advances in plant design and machine manufacture. The syooposium is open to all interested. The fee of $£ 2$ ( $£ 1$ to members of the Institution) includes a copy of the proceedings. Further details can be obtained from the Secretary of the Institution at Salisbury House, Finsbury Circus, London, E.C.2.

\section{Beta- and Gamma-Radioactivity: Conference in Amsterdam}

THE Netherlands Physical Society, under the auspices of the International Union of Pure and Applied Physics and supported by Unesco, is organizing an international conference on beta- and gamma-radioactivity, to be held in Amsterdam during September 1-6. Introductory lectures will be given by leading authorities on the following subjects : beta-disintegration, allowed and forbidden transitions, and $k$-capture; gamma-transitions and internal conversion; systematics of beta- and gamma-decay and the shell model; angular and polarization correlations; critical discussion of instruments for beta- and gamma-spectroscopy; energy calibration; measurements on nuclear recoil and detection of the neutrino. Short communications of about fifteen minutes duration may be made at the main sessions and at the sectional meetings, and those intending to make such communications should write to the secretary of the conference, Prof. J. de Boer, Bunsenstraat 98, Amsterdam-O, from whom further information can be obtained.

\section{Nutrition Society: New Officers}

THE following new appointments have been made in the Nutrition Society : Treasurer, Dr. A. J. Amos (Laboratories, Dudden Hill Lane, Willesden, London, N.W.10) ; Programmes Secretary, Dr. R. J. Allen (Monkhouse and Glasseock, Ltd., Snowsfields, London, S.E.1) ; Secretary, Dr. G. H. Bourne (London Hospital Medical College, Turner Street, London, E.1); Members of Council, Dr. J. D. Hourihane, Dr. E. C. Owen, Dr. R. Passmore and Dr. H. M. Sinclair. All queries regarding the Society's meetings and symposia should be directed to Dr. Allen.

\section{Announcements}

THe Lavoisier Medal of the Société Chimique de France has been presented to Prof. F. A. Paneth, professor of chemistry in the University of Durham.

'THE fourteenth awaı' of the William Bowie Medal of the American Geophysical Union (Committee on Geophysics of the National Research Council) has been made to Prof. Harold Jeffreys, Plumian professor of astronomy and experimental philosophy in the University of Cambridge, for his contributions to geophysics, and in particular for his work on co-operation in geophysical research through the agency of the International Union of Geodesy and Geophysics. The Medal was first awarded in 1939 to the late William Bowie, geodesist and geophysicist, after whom it is named.

THE National Research Council of Canada is offering ten postdoctorate fellowships, worth 3,000 dollars a year for two years $(3,500$ dollars for married men), for scientific research to be undertaken at Canadian universities. In addition to the fellowship stipend, a grant may be made for the purchase of apparatus of up to 2,000 dollars during the first year and 1,000 dollars during the second. Applicants may be of any nationality, but must be less than thirtyfive years of age; at least half the fellowships will be awarded to Canadians. Further information can be obtained from the National Research Council, Ottawa 2. 